\title{
Hydrofluoric Acid Burn Management - Case Presentation
}

\author{
Sabina GRAMA ${ }^{1}$, Andreea BULARDA ${ }^{1}$, Mihaela ANDREI', Tiberiu Paul NEAGU ${ }^{1,2}$, Serban Arghir \\ POPESCU1,2, Camelia Cristina DIACONU ${ }^{3,4}$, Ovidiu Gabriel BRATU5,6, Dan IONESCU ${ }^{1}$, Liviu TIGANIUC, \\ Ioan LASCAR ${ }^{1,2}$
}

\begin{abstract}
Background: Hydrofluoric acid (HF) is an extremely dangerous weak inorganic acid, which can produce extensive burn lesions, depending especially on the solution concentration and exposure time, systemic toxicity occurring in patients with large burn areas, high concentration of acid or an extensive time of exposure. The subcutaneous infiltration and intravenous administration of calcium gluconate is essential for preventing dyselectrolytemia and severe pain appearance. Case summary: A 26-year-old man patient presented to our hospital after a hydrofluoric burn, secondary to an occupational accident. At the scene, the wound was irrigated with fresh water and topical calcium gluconate was applied. In the Emergency Department, we started the intravenous calcium gluconate administration, and in the Burn Unit it was injected subcutaneously and the pain was thus diminished. A prolonged QT interval was identified upon admission that has been corrected over the next few days. Particularly, the serum pseudocholinesterase levels were within normal range. The local treatment involved repeated copious lavage with sterile water and Betadine solution, the evolution being rapidly favorable with the burn lesions completely healed in the next week. Conclusion: HF burns are a very special type of chemical burn taking into account that exposure to a small quantity of solution can be life threatening and that the immediate treatment is mandatory in order to maximize the outcome. It is of vital importance that any medical facility had a chemical burn protocol.
\end{abstract}

Keywords: hydrofluoric acid exposure, burn, calcium gluconate, arrhythmias.

\section{Rezumat}

Introducere: Acidul hidrofluoric este un acid inorganic slab extrem de periculos, ce poate produce extinse leziuni de arsură, ce depind în special de concentrația soluției și de timpul de expunere, toxicitatea sistemică survenind la pacienții cu arsuri întinse, concentrații mari de acid sau timp crescut de expunere. Infiltrarea subcutanată și administrarea intravenoasă de gluconat de calciu este esențială pentru a preveni apariția diselectrolitemiilor și a durerilor

\footnotetext{
1 Department of Plastic Surgery and Reconstructive Microsurgery, Emergency Clinical Hospital, Bucharest, Romania

${ }^{2}$ Clinical Department No. 14, „Carol Davila" University of Medicine and Pharmacy, Bucharest, Romania

${ }^{3}$ Department of Internal Medicine, Emergency Clinical Hospital, Bucharest, Romania

${ }^{4}$ Clinical Department No. 5, „Carol Davila" University of Medicine and Pharmacy, Bucharest, Romania

${ }^{5}$ Department of Urology, „Dr. Carol Davila" Emergency University Central Military Hospital, Bucharest, Romania

${ }^{6}$ Clinical Department No. 3, „Carol Davila” University Medicine and Pharmacy, Bucharest, Romania

${ }^{7}$ Department of Anesthesiology and Intensive Care, Emergency Clinical Hospital of Bucharest, Romania
}

\section{Corresponding author.}

Tiberiu Paul NEAGU, Department of Plastic Surgery and Reconstructive Microsurgery, Emergency Clinical Hospital, $8^{\text {th }}$ Floreasca Avenue, $1^{\text {st }}$ District, 01446, Bucharest, Romania. E-mail: dr.neagupaul@gmail.com 
severe. Prezentare de caz: Prezentăm cazul unui pacient de 26 ani cu o arsură post-expunere la acid hidrofluoric, secundară unui accident de muncă. La locul accidentului, rana a fost toaletată cu apă și a fost aplicat local gluconat de calciu. În Departamentul de Urgență, s-a inițiat administrarea de gluconat de calciu intravenous, iar în Unitatea de îngrijirea a pacienților cu arsuri acesta a fost injectat subcutanat, diminuând astfel intensitatea durerii. Încă de la admisie s-a identificat pe electrocardiogramă o prelungire a intervalului QT, dar care s-a corectat pe parcursul câtorva zile. În mod particular, nivelul pseudocolinesterazei serice a fost normal. Tratamentul local a presupus toaletă abundentă cu apă sterilă și soluție de betadină, evoluția fiind rapid favorabilă, cu vindecarea completă a arsurilor în decurs de câteva săptămâni.

Concluzii: Arsurile prin acid hidrofluoric reprezintă un tip special de arsuri chimice, ținând cont de faptul că expunerea la o cantitate mică de substanță poate produce complicații amenințătoare de viață și că intervenția terapeutică trebuie să fie promptă pentru a ameliora prognosticul pacienților. De asemenea, este esențial ca orice unitate sanitară ce se ocupă de îngrijirea pacienților cu arsuri să dețină un protocol standardizat de management al pacienților cu arsuri chimice.

Cuvinte cheie: expunere la acid hidrofluoric, arsură, gluconate de calciu, aritmii.

\section{INTRODUCTION}

Medical treatment of hydrofluoric acid (HF) exposure is highly specialized, many physicians not being familiar with the appropriate management. HF is an extremely dangerous weak inorganic acid, due to fluoride ions in its structure, being largely used as an industrial raw material, industrial cleaning agent and in household cleaning ${ }^{1}$.

The HF concentration is essential for the initial assessment and treatment. It is important to know that the exact concentration of $\mathrm{HF}$ and the exposure duration in order to immediately initiate the correct treatment and thus to minimize the patient morbidity and mortality ${ }^{1}$. HF can produce burns in the liquid or vaporous state. Burns larger than $160 \mathrm{~cm}^{2}$ have serious systemic toxicity ${ }^{1}$. Low concentrations of HF $(<20 \%)$ are less dangerous and acidic, compared to high concentrations ( $>20 \%)$ which can be deadly and must be immediately treated ${ }^{2}$.

Consisting with the findings of Kirkpatrick and Burd et al. ${ }^{3}$ and Upfal and Doyle ${ }^{4}$, the severity rises in some cases, like a concentration $>50 \% \mathrm{HF}$ is, an exposure more than $5 \%$ of the body area, inhalation or ingestion of $\mathrm{HF}^{4}$. The poisoning severity can also rise if there is an increased duration of exposure ${ }^{5}$.

HF skin burns elicit severe pain in the affected area ${ }^{1}$, probably related to the released hydrogen and fluoride ions in contact with normal cations (calcium, magnesium $)^{5}$. Hydrogen ions cause a deep corrosive burn with serious complications, and the fluoride ions cause liquefaction necrosis ${ }^{2}$.

Regarding systemic toxicity, the main concern is related to the electrolyte disturbances, especially hypocalcemia, hypomagnesemia, acidosis, hepatic, neurolo- gic and cardiac disturbances ${ }^{2}$, due to fluoride ions binding with usual ions. Apparently, these ions manifest direct toxicity on myocardial cells due to the fact that they inhibit the adenylate cyclase, therefore, the serum electrolyte levels monitoring is mandatory ${ }^{3}$.

In the department of emergency, the infiltration of subcutaneous tissue with calcium gluconate solution may reduce the pain. If the burn is localized on the hand, palmar fasciotomy may be taken into consideration, seeing that the infusion of calcium gluconate may cause compartment pressure and necrosis, especially in fingers. Intra-arterial calcium infusion is also used in patients with severe HF burns of fingers, face and lower extremities ${ }^{2}$.

Immediate surgical excision of the burn areas may be performed if systemic toxicity develops, requiring the maximum intensive care treatment in order to remove the source of fluoride ions ${ }^{6}$. It also involves irrigation of the burn area with water for at least 15-30 minutes, which prevents rapid skin penetration ${ }^{2}$. Surgical treatment involves blisters debridement, eschars excision, and multiple debridement with auto grafting the defects or using allograft and xenograft for unclean wound bed ${ }^{6}$.

\section{CASE PRESENTATION}

A 26-year-old man patient presented to our hospital after a hydrofluoric burn, secondary to an occupational accident, in an industrial building. He was working with a hydrofluoric acid solution when drops with a concentration of $17 \% \mathrm{HF}$ slipped over his left arm. At the scene, the coworkers irrigated the wound with water and applied topical calcium gluconate. In the emergency department, the intravenous infusion of calcium 
gluconate was started, after a rapidly evaluation and monitoring. The local exam revealed an erythematous lesion localized in the anterior-intern distal part of the left arm, of about $10 / 10 \mathrm{~cm}$, with moderate pain, normal mobility, sensitivity, pulse and distal capillary refill, but with erythematous and edematous skin adjacent to the burn. Calcium gluconate was immediately injected subcutaneously in the involved area (Figure 1). The patient was conscious, hemodynamically and respiratory stable and the burn area was almost painless. After the admission in the Burn Unit, we started the standard examination, like serial ECG, chest X-ray, arterial blood tests and permanent monitoring. The recorded

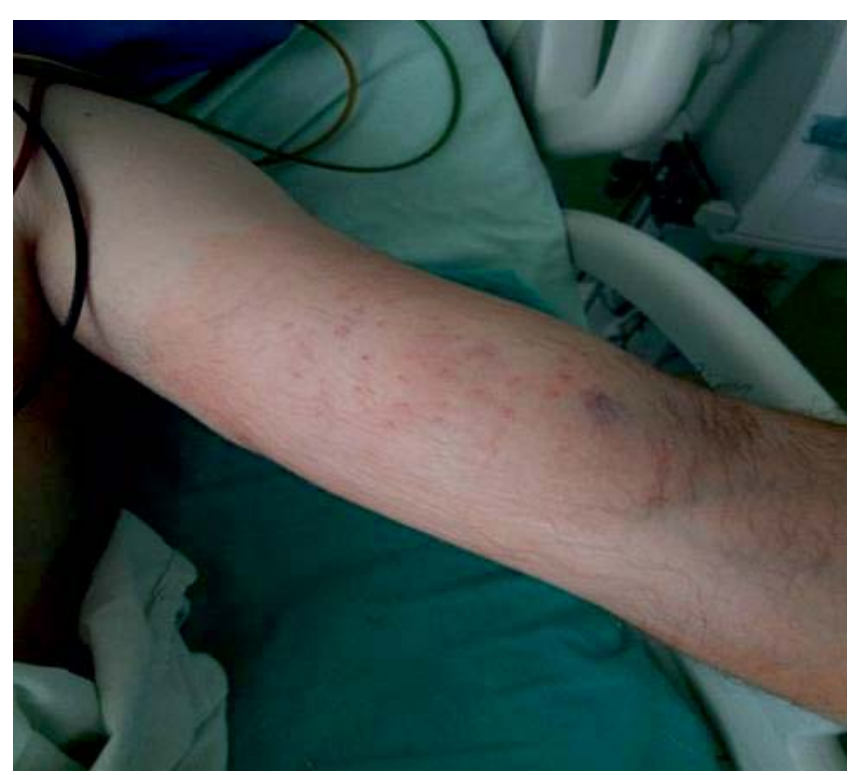

Figure 1. Hydrofluoric acid burn after injection of calcium gluconate.

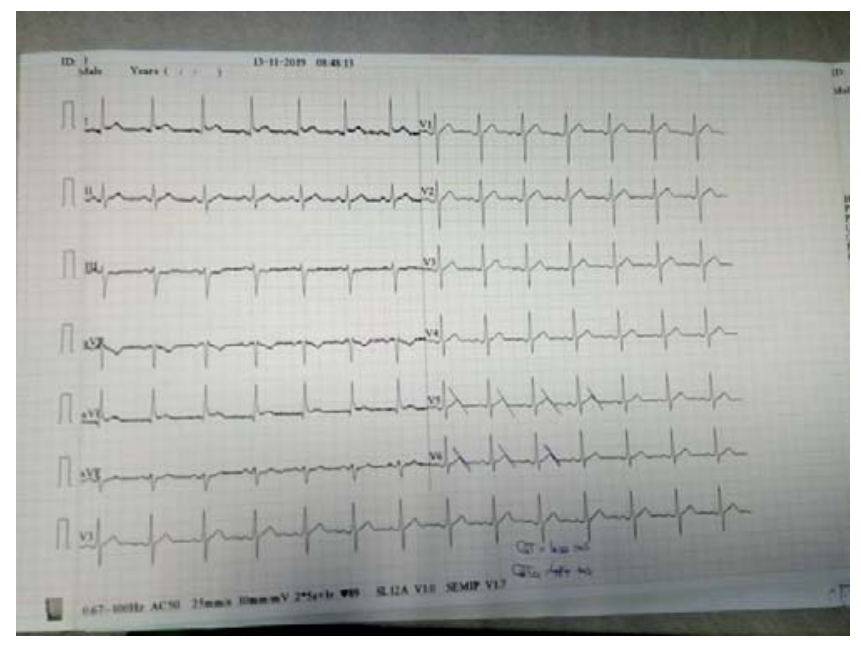

Figure 2. EKG at admission revealing a prolonged QTc interval.
ECG trace showed a slightly prolonged QT interval (Figure 2) and the blood gas test revealed a mild metabolic acidosis. The calcium, sodium and potassium levels and the ECG trace were monitored all over the admission period, with blood gas tests performed every 2 to 4 hours in the first few days. In addition to the normal burn therapy protocol, the calcium gluconate solution was continuously infused (Figure 3). As HF poisoning can alter serum pseudocholinesterase levels, we measured them specifically and in our case and the values were within normal limits. The local treatment involved copious lavage with sterile water and Betadine solution, the evolution being rapidly favorable with the burn lesions completely healed over the next week (Figure 4-6). The serum calcium levels were constantly monitored for adjusting the calcium gluconate infusion rate, with the QT interval normalizing and maintaining a normal value through the admission period ( $\mathrm{Fi}^{-}$ gure 7 ). The treatment was stopped after 7 days when the calcium levels returned to normal value. The evolu-

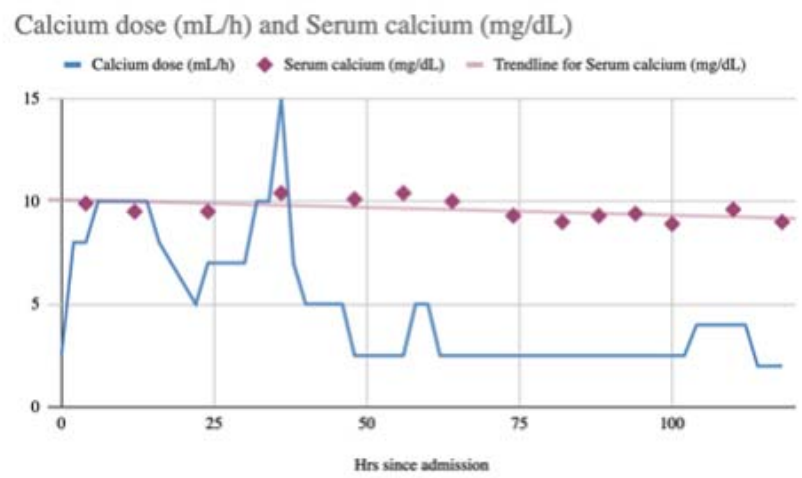

Figure 3. Dynamic evolution of calcium doses administration and serum calcium levels.

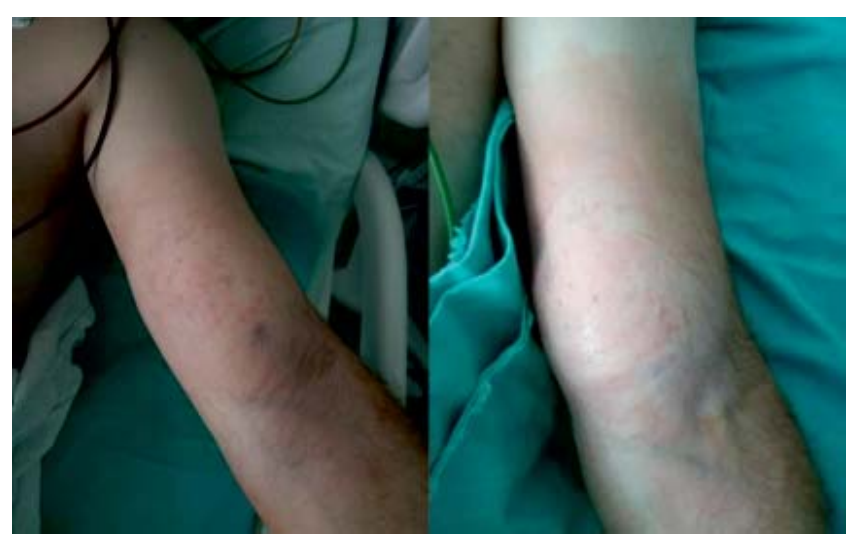

Figure 4. Burn evolution in day 2 and 4. 


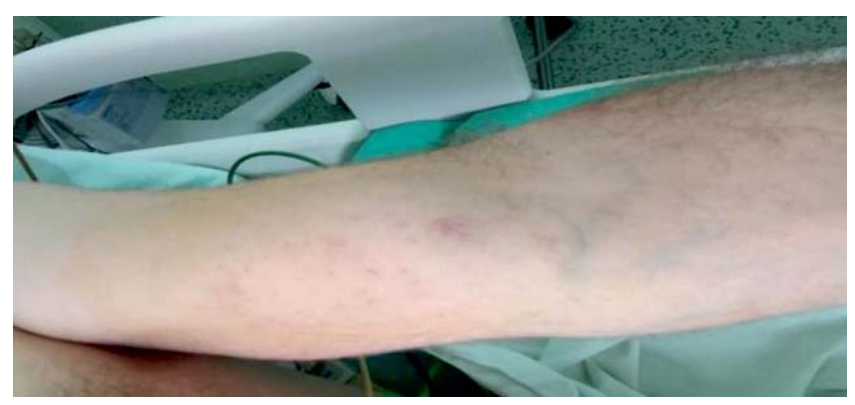

Figure 5. Burn evolution in day 6.

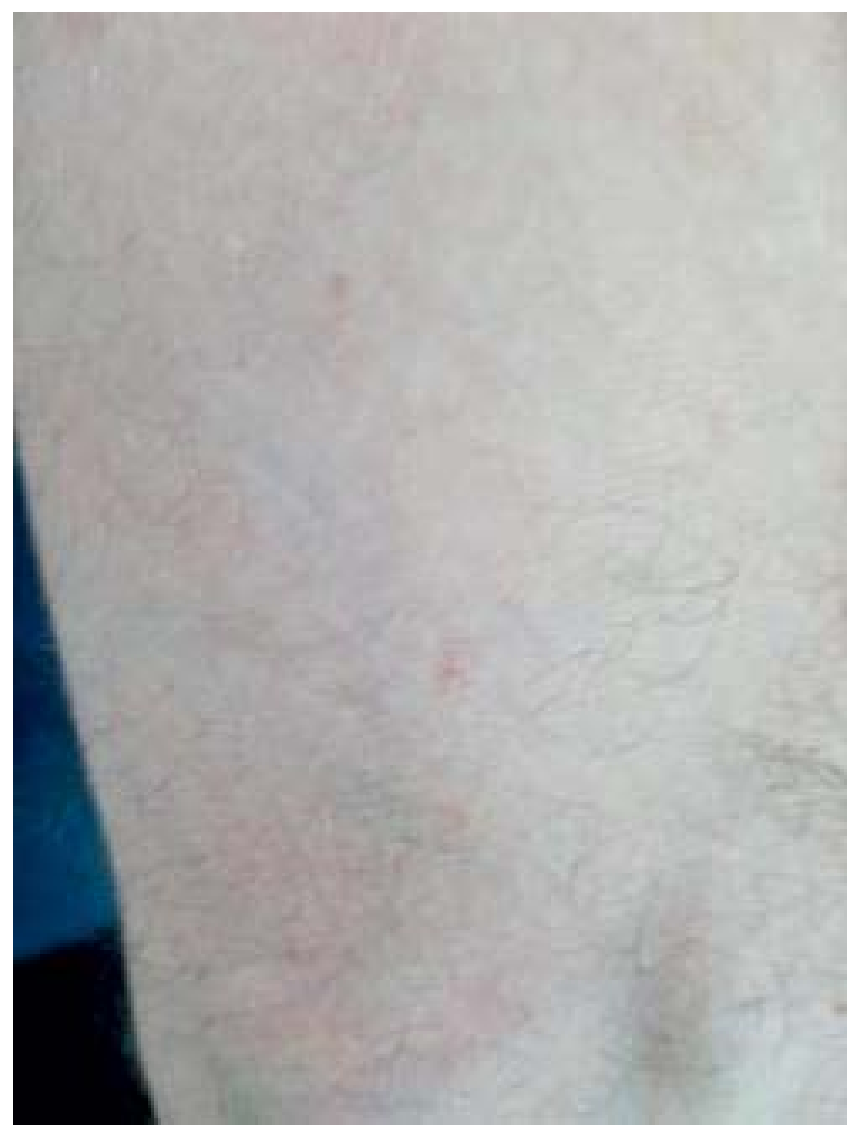

Figure 6. Local evolution after 14 days.

tion was favorable and the patient was discharged into the surgical ward after 8 days of intensive care staying.

\section{DISCUSSION}

In this type of burn lesions, the patient outcome is strictly related with the HF concentration, the exposure duration and the immediate and correct treatment ${ }^{2}$. This chemical burn can be lethal if the treatment is delayed or inappropriate, the systemic poisoning being the most dangerous component of HF burns. It can

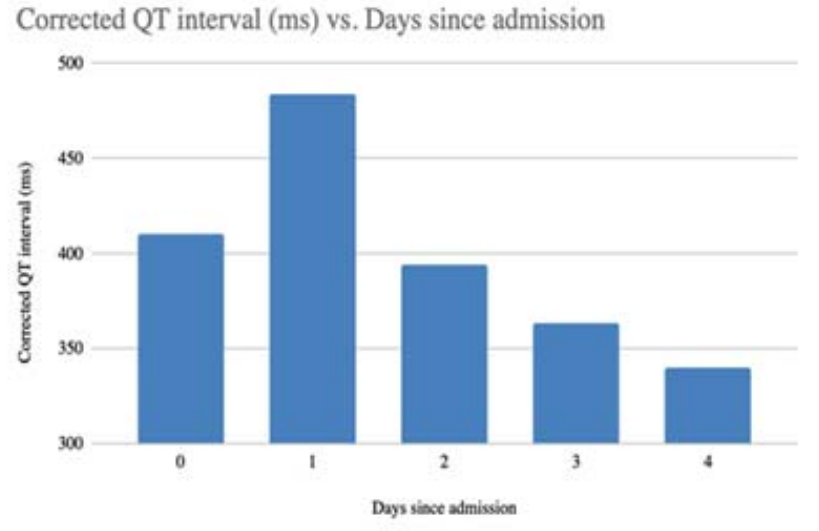

Figure 7. Dynamic evolution of corrected QT interval.

induce various symptoms, especially nausea, vomiting, abdominal pain, convulsions, hypotension, cardiac arrhythmias and cardiac failure ${ }^{7}$. However, in our case, the exposure time was short and the treatment very prompt, therefore the systemic manifestation was faded.

Studies have shown that calcium replacement must begin even before the serum calcium levels are determined. If serum hypocalcaemia is already present, the appropriate treatment involve intravenous calcium gluconate infusion, hemodialysis if the potassium and fluoride serum levels are very high or to treat refractory hypocalcemia ${ }^{4}$. For our patients, calcium gluconate infusion was started in the emergency department and after that, it was immediately injected subcutaneously in the affected area, reducing the pain intensity.

Clinical evidence of hypocalcaemia is not usually present, thus, ECG monitoring is important, in order to show the presence of a prolonged QT interval or arrhythmias and to prevent fatal events ${ }^{2}$.

It is well known that an important aspect in managing patients with hydrofluoric acid burn involve absorption prevention to minimize tissues destruction ${ }^{8}$. HF rapidly penetrates the tissues because it is a lipophilic molecule. Zhang Y, Tepperman and al. emphasize the fact that there are some areas, like neck and face, where the HF can be quickly absorbed into systemic circulation with consecutive poisoning and death ${ }^{9,10}$. Therefore, wound irrigation with water and topical application of calcium gluconate at the scene was a decisive element for our patient favorable outcome ${ }^{11}$.

Regarding fluoride excretion, it happens via the kidney, with half of the HF concentration being eliminated during the first 24 hours after exposure. However, 
Hydrofluoric Acid Burn Management - Case Presentation

it is well known that these ions have toxic effects on the nephrons, with consecutive inhibition of sodium and chloride. Stimulating kidney function using diuretics to obtain an increased urine volume is usually used in cases with important systemic toxicity ${ }^{12}$. In case of systemic poisoning, there are some reported case about the use of continuous renal replacement therapy for removing the circulatory fluoride and for correcting acidbase and electrolyte disturbances ${ }^{13}$.

\section{CONCLUSIONS}

HF burns are a very special type of chemical burn. It must be taken into consideration that exposure to a very small amount of solution can be life threatening, especially through cardiac arrhythmias, therefore the immediate treatment being mandatory in order to ma-

\section{References}

1. Recommended medical treatment for hydrofluoric acid exposure Honeywell Industrial Fluorines Technical Service Manager - Hydrofluoric Acid Honeywell Performance Materials and Technologies bor Road Morris Plains, NJ 07952

2. D McKee, A Thoma, K Bailey, J Fish. A review of hydrofluoric acid burn management. Plast Surg 2014;22(2):95-98.

3. Fang $H$, Wang GY, Wang $X$, He F, Su JD. Potentially fatal electrolyte imbalance caused by severe hydrofluoric acid burns combined with inhalation injury: A case report. World journal of clinical cases. 2019 Oct 26;7(20):3341.

4. Ming-Ling W, Juo-Fang D, Ju-Sing F. Survival after hypocalcemia, hypomagnesemia, hypokalemia and cardiac arrest following mild hydrofluoric acid burn. Clin Toxicol 2010;48:95355.

5. Kirkpatrick J, Burd D. Hydrofluoric acid burns: A review. Burns 1995;21:483-93

6. Upfal M, Doyle C. Medical management of hydrofluoric acid exposure. J Occup Med 1990:726-31.

7. Ohtani M, Nishida N, Chiba T, et al. Pathological demonstration of rapid involvement into the subcutaneous tissue in a case of fatal hydrofluoric acid burns. Forensic Sci Int 2007;167:49-52. ximize the outcome. Topical, subcutaneous and intravenous calcium plays a decisive role in HF burn treatment. Surgical intervention is required only in cases with extensive burn lesions.

Regarding the extent of the chemical burns, it is very important for the medical staff to understand the importance of rapid management of these types of chemical burns and we strongly recommend that a chemical burn protocol must exist in any medical facility.

Compliance with ethics requirements: The authors declare no conflict of interest regarding this article. The authors declare that all the procedures and experiments of this study respect the ethical standards in the Helsinki Declaration of 1975, as revised in 2008(5), as well as the national law. Informed consent was obtained from all the patients included in the study.

8. Wang S, Dai G. Hydrofluoric acid burn. CMAJ. 2019 Mar 18;191(11):E314-.

9. Zhang Y, Wang X, Liu Y, Jiang X, Ye C, Ni L, Zhang L, Zhang J, XU $B$, Han $C$. Management of a rare case with severe hydrofluoric acid burns: important roles of neutralizers and continuous renal replacement therapy. The international journal of lower extremity wounds. 2017 Dec;16(4):289-95.

10. Burd A. Hydrofluoric acid-revisited. Burns. 2004;7(30):720-2

11. Han HH, Kwon BY, Jung SN, Moon SH. Importance of initial management and surgical treatment after hydrofluoric acid burn of the finger. Burns. 2017 Feb 1;43(1):e1-6.

12. Wang X, Zhang Y, Ni L, You C, Ye C, Jiang R, Liu L, Liu J, Han C. A review of treatment strategies for hydrofluoric acid burns: current status and future prospects. Burns. 2014 Dec 1;40(8):144757.

13. Björnhagen $V$, Höjer J, Karlson Stiber C, Seldén Al, Sundbom M Hydrofluoric acid induced burns and life threatening systemic poisoning-favorable outcome after hemodialysis. Journal of Toxicology: Clinical Toxicology. 2003 Jan 1;41(6):855-60. 
